\title{
Entre a Justicialização Privada e o Estado De Exceção: A (Re)Criação Anômica da Sociedade
}

\author{
Alfredo Copetti Neto \\ Doutor em Direito pela Università di Roma. Mestre em \\ Direito pela Unisinos. Cumpriu estágio pós-doutoral \\ CNPq/Unisinos. Professor PPG - Unijuí e Unioeste. Advo- \\ gado OAB-RS. alfredocopetti@yahoo.com
}

\section{Linckse Bianca Oliveira Ramires}

Bacharel em Direito pela Faculdade de Ciências Sociais Aplicadas de Cascavel - Univel. Advogada OAB-PR. linckse_bianca@hotmail.com

\section{Resumo}

0 estudo aqui apresentado faz uma análise sobre a violência na atual conjuntura, mormente no que se refere à justiça privada - linchamentos - como meio de resolução imediata de conflitos, bem como a forma como o Estado, por meio de seu Soberano, se impõe diante da atual crise social. A pesquisa traz à tona a questão sobre a tensão existente entre a obediência e a transgressão da norma estabelecida e, para tanto, parte do exemplo privilegiado de Antígona para abordar a questão do conflito entre o direito positivo e o direito natural. Segue expondo os casos e as explicações acerca do fenômeno social da justicialização privada e, na sequência, exibe a forma com que o Estado também tem feito justiça com as próprias mãos, mediante este novo paradigma de governo que se instala sob a forma de exceção. Para melhor compreensão do tema é feita uma análise utilizando-se as obras de Giorgio Agamben e Gilberto Bercovicci, as quais sugerem a possibilidade de um estado de exceção permanente diante das condutas arbitrárias de governo.

Palavras-chave: Justicialização privada. Estado de exceção. Estado democrático de Direito. Linchamentos. 


\title{
Between Private Justice's Increase and State of Exception: The Anomic (Re)Creation of Society
}

\begin{abstract}
This study is about violence in the current conjuncture. It is focused on private justice - like lynching as an immediate way of solving conflicts - and it also brings up which is the sovereign State's imposition about the social crisis. It explores the tension that exists between obedience and established norm's transgression and, therefore, starts from the privileged example of Antigone to explore the conflict between positive and natural law. This research brings cases and explanations about the social phenomenon of private justice's increase, followed by an approach that exposes how the government is also making justice by its own hands, through this new political paradigm that is being settled by exception's form. For a better understanding of this study's subject, the works of Giorgio Agamben and Gilberto Bercovicci were analysed. Those works suggest the possibility of a permanent state of exception due to government's arbitrary conduct.
\end{abstract}

Keywords: Private Justice's Increase. State of exception. Democratic state. Lynching.

Recebido em: 19/1/2016

Aceito em: $29 / 5 / 2017$

\section{Sumário}

1 Introdução. 2 Norma jurídica: obediência ou transgressão? 2.1 Direito natural e direito positivo: aspectos gerais e históricos. 2.2 Antígona e 0 embate entre a justiça e a lei. 3 Entre a justicialização privada e 0 estado de exceção. 3.1 Da violência das ruas à violência institucionalizada. 3.2 A emergência do homo sacer no cenário brasileiro. 3.3 Violência legitimada: quando a exceção se torna regra. 4 Considerações finais. 5 Referências. 


\section{INTRODUÇÃO}

A Constituição da República Federativa do Brasil, já no seu artigo $1^{\circ}$, trouxe como alicerce o Estado Democrático de Direito, pelo qual se tornou possivel definir as regras básicas para o progresso da nação, bem como a proteção dos direitos e garantias fundamentais.

Neste novo cenário, pôde se verificar a proteção do cidadão em relação ao Estado e à própria sociedade, uma vez que trouxe consigo a defesa da democracia, da cidadania, da dignidade da pessoa humana e da liberdade como meio de efetivar o bem-estar social.

O presente trabalho tem por finalidade analisar a relação entre Direito e indivíduo no Estado ante as mudanças no cenário social mormente a intensificação dos casos de justicialização privada, a qual traz à tona a questão da legitimidade das normas jurídicas e os desafios que uma sociedade enfrenta quando escolhe viver sob a égide do direito.

As situações envolvendo a chamada justiça popular têm aumentado de maneira assustadora, indicando, assim, a necessidade de um estudo a respeito de tais acontecimentos, isto porque a sociedade atual tem clamado por justiça além dos limites legais, revelando a descrença no sistema Judiciário e colocando o Estado em crise.

Ao lume dessas circunstâncias e para o melhor desenvolvimento dessas questões, foi escolhida a tragédia grega Antígona, de Sófocles, pela qual foi possível analisar um dos mais importantes embates entre o direito natural (justiça) e o direito positivo (lei).

A questão abordada na tragédia analisada é trazida aos dias atuais para melhor entender a relação entre indivíduo e Estado, as consequências de uma vida regrada pelo direito, bem como os motivos que leva o indivíduo a obedecer ou transgredir as leis estabelecidas. 
Seguir-se-á, assim, o estudo do problema central da pesquisa, o qual se mostra como ato contrário ao Estado Democrático de Direito, e cuja discussão maior reside na violência praticada pelo Estado, o que desvela a possibilidade de um estado de exceção permanente como paradigma do governo que, ante a ausência de respostas adequadas, se impõe de forma repressiva e até mesmo tirânica.

Partindo desta premissa, a proposta maior do trabalho é mostrar o panorama de exceção e a forma como os direitos e garantias contemplados pela atual Constituição têm sido grandemente ameaçados, sob o fundamento da própria ordem democrática, resultando num desequilíbrio constitucional.

A exceção, que já está virando regra, gira em torno da relação entre direito/política e soberania/democracia, isto porque é comum que tanto o direito quanto a democracia estão à mercê do Soberano (Estado) que não se mostra preocupado com a sociedade em si, mas, sim, com a política consubstanciada na forma de manutenção de poder.

A metodologia de abordagem utilizada na presente pesquisa foi pautada no método fenomenlógico-hermenêutico. Assim, convém esclarecer que a fenomenologia hermenêutica não é, conquanto, um método no sentido cartesiano, que edifica verdades a partir de sua aplicação, mas uma forma de fazer filosofia, o que somente é possível colocando-a em movimento enquanto um filosofar.

\section{NORMA JURÍDICA: Obediência ou Transgressão?}

\subsection{Direito Natural e Direito Positivo: aspectos gerais e históricos}

Para adentrar neste estudo é necessário trilhar um caminho partindo da velha dicotomia direito natural $\mathrm{x}$ direito positivo e prosseguindo até a questão da aplicação e transgressão da norma jurídica na socie- 
dade regida pelo direito. A indagação acerca da natureza do significado de direito positivo e direito natural é trazida desde a Antiguidade até a contemporaneidade, sendo objeto de estudos de grandes pensadores do direito e alvo de diversas discussões.

A tradição do pensamento jurídico ocidental, até o final do século 18 , foi determinada pela divisão entre direito positivo e direito natural. A vertente desta separação se justifica na própria distinção entre essas duas áreas do direito e tem suas raízes identificadas em Platão, em que podem ser visualizadas as expressões justiça positiva e justiça natural; a primeira ligada às leis reguladoras da vida social e a segunda intimamente ligada ao cosmo (criação e constituição do universo).

As diferenças entre as duas matérias também está presente na concepção de Aristóteles, quando o direito positivo é visto como aquele de característica puramente normativa, colocado por regras sociais, as quais, uma vez estabelecidas, devem ser observadas, ao mesmo tempo em que o direito natural é eficaz em qualquer parte, independentemente do corpo social e das normas impostas. Esse entendimento é visualizado no capítulo VII do Livro V de sua Ética a Nicômaco, como cita Peble (apud BOBBIO, 1995):

Da Justiça civil uma parte é de origem natural, outra se funda em lei. Natural é aquela justiça que mantém em toda a parte o mesmo efeito e não depende do fato de que pareça boa a alguém ou não; fundada na lei é aquela, ao contrário de que não importa se suas origens são estas ou aquelas, mas sim como é, uma vez sancionada (p. 17).

Destarte, o direito natural é aquele que tem por toda a parte e está associado a um sistema de normas insubordinadas ao direito positivo, podendo ser entendido como uma ideia abstrata de ordenamento jurídico, posto que este direito independe das leis reguladoras da vida social que se originam do Estado, enquanto o direito positivo estabelece ações cuja 
eficácia se manifesta apenas na comunidade política em que é posto, não podendo ser cumpridas por maneira diversa ao que a lei imperativamente prescreveu.

Como expõe Bobbio (1995), o direito romano também acolheu a diferenciação entre o direito natural e o direito positivo a partir da conceituação de jus gentium e jus civile.

O direito natural é aquele em que a natureza ensina a todos os animais... O direito civil e o direito das gentes devem ser distinguidos: todos os povos que são regidos por leis e pelos costumes têm um direito que lhes é próprio em parte e em parte comum a todos os homens. Com efeito, o direito que cada povo estabelece para si mesmo é o direito próprio à cidade: chama-se direito civil porque é o direito especial da cidade. Mas o direito que a razão natural estabeleceu entre os homens, que é igualmente observado entre todos os povos, chama-se direito das gentes, isto é, direito de todas as nações (p. 18).

A distinção romana estabelece, também, que o direito positivo é limitado a um determinado povo, sendo colocado por uma entidade social criada por homens, enquanto o direito natural não sofre limitações e é posto pela razão natural.

Bobbio (1995) continua lecionando que, "Enquanto, pois, o direito natural permanece imutável no tempo, o direito positivo muda (assim como no espaço) também no tempo, uma norma pode ser anulada ou mudada, seja por costume seja por efeito de outra lei”.

Na compreensão medieval, em que predomina o pensamento cristão, a distinção do direito positivo e natural encontra apoio em Abelardo, filósofo medieval do século 11, o qual doutrina que o direito natural é apresentado por algo/alguém superior aos homens que impõem o direito positivo. Esse entendimento é seguido por Santo Agostinho, que estipu- 
lou e resgatou a noção de direito natural, distinguindo a lei eterna (lex aeterna) e a lei natural (lex naturalis), sendo a primeira emanada de Deus e a segunda a manifestação do homem (BOBBIO, 1995).

São Tomás de Aquino prossegue trazendo a lex naturalis e a lex humana que correspondem à distinção entre direito natural e direito positivo, no sentido de que a lex naturalis trata daquilo que se convenciona na práxis - pela maioria - e a lex humana a que deriva por obra do legislador e a põe valer.

Conforme Bobbio, a ideia de que o direito natural se sobrepõe ao direito positivo é uma herança do pensamento medieval e "desta concepção do direito natural como inspiração cristã derivou a tendência permanente no pensamento jusnaturalista de considerar tal direito como superior ao positivo" (1995, p. 19).

No direito moderno a concepção dualista do direito é devida também a Hugo Grócio, o qual formula a distinção entre jus naturale $\mathrm{e}$ jus voluntarium.

O direito natural é um ditame de justa razão destinado a mostrar que um ato é moralmente torpe ou moralmente necessário segundo seja ou não conforme a própria natureza racional do homem, e a mostrar que tal ato é, em consequência disto, vetado ou comandado por Deus, enquanto autor da natureza (GROCIO apud BOBBIO, 1995, p. 20-21).

Assim, encontrando apoio em princípios racionais, Hugo Grócio segue na direção de que o direito é um apanhado de normas ditadas pela razão e não por uma revelação divina, sendo, portanto, o direito natural independente da vontade de Deus, pois existiria mesmo que Deus não existisse.

Seguindo um pensamento contrário ao de Hugo Grócio, o filósofo inglês Thomas Hobbes negava ao homem a condição de animal social; eis que o homem era por ele considerado um ser absolutamente egoísta, pro- 
penso apenas aos seus interesses e despreocupado com seus semelhantes. Hobbes distingue a lei civil da lei natural como sendo, a primeira, advinda do Estado, não podendo ser contrária à razão, e a segunda consistente na condição de simples natureza, e não são consideradas leis propriamente ditas se não forem submetidas ao crivo do Estado (BOBBIO, 1995).

Em Rousseau, o homem é bom por natureza, e sem os comandos políticos do Estado os seres humanos viviam o pleno exercício de seus direitos naturais, condição esta que é derrubada pela desarmonia da sociedade civil, o que acarretou a necessidade de um contrato social com o intento de recuperar o bem-estar primitivo, oportunidade em que os homens transferiram seus direitos naturais ao Estado em troca de direitos civis. Sendo assim, entende-se que "o que o homem perde pelo contrato social é a liberdade natural e um direito limitado a tudo o que tenta e pode alcançar; o que ganha é a liberdade civil e a propriedade de tudo o que possui” (ROUSSEAU, 2002, p. 30-31).

De todo o caminho percorrido sobre a dicotomia em comento, chega-se a um ponto comum e geral em que o direito natural é aquilo que é por natureza (physis), e o direito positivo aquilo que é por convenção ou posto pelos homens (thésis). Em suma, o direito natural é imutável, vale em toda a parte e é conhecido por meio da razão, ao mesmo tempo em que o direito positivo é mutável, valendo apenas em alguns lugares e conhecido mediante uma declaração de vontade alheia.

Com efeito, apesar do antagonismo relativo as duas áreas do direito, é evidente que, no decorrer de longos períodos, se estipulou uma importante discussão entre eles, que também resultou em importante e gradativa positivação dos direitos naturais. 
Denota-se, então, que, à medida que o direito positivo tem sua característica principal marcada na sua forma, o direito natural, por sua vez, se configura pela sua essência, o que significa afirmar que aquele se consubstancia nas formalidades de sua criação e que o direito natural tem seu caráter substancial ligado aos direitos que o compõe.

Seguindo esse raciocínio, pode se verificar a possibilidade de compatibilização entre esses dois temas; isto porque apesar de o direito natural ser o de mais alta hierarquia, o mesmo é composto por normas genéricas, precisando do direito positivo para garantir sua observância. Assim, sendo o direito positivo fruto da vontade soberana da sociedade, cabe a ele a tarefa de efetivar a justiça por meio do respeito ao direito natural, no qual encontra sua legitimidade.

Embora não se possa confundir o Direito Natural com a justiça, o certo é que aquela ordem constitui um ideal de Justiça e um dos caminhos que levam o pensador ao Jus Naturae é a sua intensificação com a carência de Justiça nos estatutos legais. $\mathrm{O}$ homem, ser eminentemente racional, sonda a razão de ser das coisas, não se submetendo passivamente a qualquer ordenamento. Procura-se o fundamento ético das leis e das decisões. O espírito crítico apela para a busca de orientação, de referência, na ordem natural das coisas. O Direito, como instrumento de promoção da sociedade, a de estar adequando à razão, há de se apresentar em conformidade com a natureza humana (NADER, 2014, p. 193).

Nesse entendimento, enquanto as leis positivas organizam a sociedade, o direito natural influencia as fontes que dão origem às normas jurídicas, as quais devem ser receptíveis aos princípios maiores daquele; isto porque o sistema de leis, por si só, não é suficiente para ter legitimidade, sendo necessário que o direito natural encontre o seu lugar na sociedade sob pena de restarem esquecidos os princípios gerais do direito, o que será mais bem abordado no tópico seguinte. 
No Direito contemporâneo é importante uma análise crítica e hermenêutica dessa dicotomia, a fim de exigir dos operadores jurídicos a preservação da função social e política do direito, bem como sua dialeticidade como respaldo ético para as relações jurídicas.

\subsection{Antígona e o Embate Entre a Justiça e a Lei}

A preocupação existente entre obediência e transgressão é explorada desde a Grécia Antiga, tendo na tragédia a sua maior expressão, pois as tragédias gregas eram vistas como manifestações artísticas que representavam ações sérias, concretas e de tamanha grandeza, suscetível de provocar aos espectadores grande emoção e, somente assim, ser digna de se tornar uma verdadeira obra de arte. Para Aristóteles, o espetáculo trágico resultava numa cartase, ou seja, a purgação das emoções provocadas por um drama.

Para que o drama da tragédia alcance sua finalidade é de fundamental importância caracterizar o herói trágico, sendo este o principal personagem da tragédia, responsável pela exteriorização de uma condição estranha à do cidadão comum decorrente de sua mais profunda natureza individual.

Dentre os tragediógrafos mais conhecidos do período clássico, destaca-se o dramaturgo grego Sófocles, cujo trabalho foi um dos mais importantes e reconhecidos da Grécia, ficando ao lado de Ésquilo e Eurípedes, grandes representantes do teatro grego.

As mais dramáticas e fascinantes tragédias gregas são apresentadas ao público na trilogia tebana de Sófocles, a qual conta com Édipo Rei, Édipo em Colono e Antígona.

Inobstante o fascínio do qual decorre as duas primeiras obras da trilogia tebana, este trabalho tem como objeto o estudo da última (Antígona), obra esta que ocupa um lugar em destaque na cultura universal, uma vez 
que desperta um encanto ainda maior em razão dos questionamentos que provocou em todo o decorrer da História e até nos dias atuais continua a trazer grandes indagações.

A partir da obra de Sófocles é possível exemplificar a questão do direito natural e do direito positivo, bem como o impacto de um em relação ao outro dentro da sociedade.

A protagonista da peça sofocliana é fruto de uma relação incestuosa vivida por Édipo, que matou seu pai Laio e casou-se com sua própria mãe Jocasta. A história de Antígona tem seu apogeu quando Creonte - rei de Tebas - edita uma ordem proibindo qualquer ato fúnebre com relação à Polínices, irmão de Antígona, o qual concordou em governar Tebas de forma revezada, pelo período de um ano, com seu irmão Etéocles, após a expulsão de Édipo do reino, o que não ocorreu, posto que este resolveu permanecer no poder, ocasionando uma guerra entre os irmãos que teve como resultado a morte de um pela mão do outro (SÓFOCLES, 1998).

Após o édito proibitivo de Creonte, Antígona se vê numa situação desafiadora tomada pelo furor e o desejo de conceder as honras fúnebres a Polínices, apesar da decisão proibitiva do rei de Tebas.

Em seu diálogo com sua irmã Ismene, Antígona insiste em desafiar o Estado, representado por Creonte, e fazer os ritos fúnebres de seu irmão, sem ao menos se importar com as penas que haviam sido estabelecidas para aqueles que ousassem transgredir a ordem estatal.

ANTÍGONA - Pois não ditou Creonte que se desse a honra da sepultura a um de nossos dois irmãos enquanto nega a outro? Dizem que mandou proporcionarem justos funerais a Etéocles com a intenção de assegurar-lhe no além-túmulo a reverência da legião dos mortos; dizem também, que proclamou a todos os tebanos a interdição de sepultarem ou sequer chorarem o desventurado Polínices: sem uma lágrima, o cadáver insepulto irá deliciar as aves carniceiras que hão de banquetear-se no feliz achado. Esse é o decreto imposto pelo bom Creonte a mim e a ti 
(melhor dizendo: a mim somente); vê-lo-ás aparecer dentro de pouco tempo a fim de alardear o edito claramente a quem ainda o desconhece. Ele não dá pouca importância ao caso: impõe aos transgressores a pena de apedrejamento até a morte perante o povo todo. Agora sabes disso e muito breve irás a tu mesma demonstrar se és bem-nascida ou filha indigna de pais nobres (SÓFOCLES, 1998, p. 198).

Antígona decide por transgredir a lei e afrontar o decreto e o poderio do rei, mesmo ciente do poder absoluto que foi conferido a Creonte em uma situação de emergência da polis. Assim, movida pela convicção de que seu direito é mais válido, declara um verdadeiro grito de protesto ao rei, pois prefere morrer e cumprir com seu dever de forma que seu delito seria considerado santo perante os deuses, e se o fim the ocorresse repousaria ao lado do irmão que tanto amou e deitaria eternamente sob a terra.

Ismene, por sua vez, é colocada entre a submissão e a morte, não vê outra saída senão a obediência e, num primeiro momento, mantém-se firme perante a conduta de sua irmã por acreditar que, numa terra onde as mulheres eram consideravelmente desprovidas de direitos, se contrapor à ordem do rei seria ainda mais doloroso e teria como consequência a sua morte, sendo melhor obedecer ao governante, ainda que constrangida.

ISMENE - Pobre de mim! Pensa primeiro em nosso pai, em seu destino, abominado e desonrado, cegando os próprios olhos com as frementes mãos ao descobrir os seus pecados monstruosos; também, valendo-se de um laço retorcido, matou-se a mãe e esposa dele - era só - e, num terceiro golpe, nossos dois irmãos num mesmo dia entremataram-se (coitados!), fraternas mãos em ato de extinção recíproca. Agora que restamos eu e tu, sozinhas, pensa na morte inda pior que nos aguarda se contra a lei desacatarmos a vontade do rei e sua força. E não nos esqueçamos de que somos mulheres e, por conseguinte, não podemos enfrentar, só nós, os homens. Enfim, somos mandadas por mais poderosos e só nos resta obedecer a essas ordens e até a outras 
inda mais desolaradas. Peço indulgência aos nossos mortos enterrados mas obedeço, constrangida, aos governantes; ter pretensões ao impossível é loucura (SÓFOCLES, 1998, p. 198).

A partir do verso supramencionado, pode-se verificar a tensão entre a obediência e a transgressão da norma que foi estabelecida, bem como a divergência de conduta entre as irmãs que, apesar de se encontrarem na mesma situação, são tomadas por sentimentos oposto provindos das entranhas de suas próprias personalidades, o que revela a diferença de comportamentos dos indivíduos que compõem a mesma ordem social, política e jurídica.

Cabe referir ainda que os nomes próprios Antígona e Ismene trazem à tona o intrínseco caráter das personagens, pois em Antígona encontra-se o prefixo anti, que expressa de antemão contrariedade. Já em Ismene existe o prefixo Iso, que denota a concordância. Assim, enquanto Antígona se revolta contra a lei tirânica de Creonte, Ismene não vê outra saída a não ser respeitar a lei posta em vigência (COPETTI NETO, 2006, p. 32).

As palavras de Creonte eram firmes e autoritárias para que todas as pessoas cuidassem de suas ordens, pois acreditava que se alguém, supremo guia do Estado, não se inclina pelas decisões melhores, é merecedor de ser desprezado diante dos homens. Expõe: "Sede implacáveis com os rebeldes ao edito" (SÓFOCLES, 1998, p. 205).

A justificativa empregada por Antígona para defender sua atitude foi pautada nas leis não escritas instituídas pelos deuses, isto é, o direito natural em contrapartida ao direito positivo manifestado pela decisão de Creonte.

A partir de então se verifica que o enfoque central de Antígona é evidenciado em torno do embate entre a ordem positivada de Creonte e a justiça divina inerente à pessoa e evocada por Antígona. 
O rei de Tebas encarna o dever de obediência às leis do Estado, enquanto a heroína preserva o dever de ouvir a própria consciência e considera que o direito positivo encontra legitimidade; contudo, uma vez colocado de encontro com o direito natural, também descobre sua limitação.

Antígona desafiou a concepção positivista da norma fazendo com que Creonte se mantivesse irredutível em sua decisão, condenando-a a ser sepultada viva em uma caverna subterrânea.

CREONTE - Levando-a por deserta estrada hei de enterrá-la numa caverna pedregosa, ainda viva, deixando-lhe tanto alimento quando baste para evitar um sacrilégio; não desejo ver a cidade maculada. Lá, em prece ao deus dos mortos - único que ela venera - talvez obtenha a graça de não perecer, ou finalmente aprenderá, embora tarde, que cultuar os mortos é labor perdido (SÓFOCLES, 1998, p. 230).

O coro que aparentemente expressava a opinião pública reconheceu a glória de Antígona ao encontro de seu derradeiro suspiro.

CORO - Mas partes para o mundo tenebroso dos mortos gloriosa e exalçada, sem que as doenças aniquiladoras te houvessem atingido, sem que as armas mortíferas ferissem o teu corpo; é por tua vontade e decisão que tu, apenas tu entre os mortais, descerás viva à região das sombras (SÓFOCLES, 1998, p. 231).

Contrariando o fim que Creonte lhe havia traçado, Antígona, mais uma vez, se rebela de forma a contrariar a ordem estabelecida e se suicida no interior do calabouço, onde posteriormente é encontrada por Creonte, estrangulada em laço improvisado com seu próprio véu de linho.

Tardiamente, Creonte se arrepende de sua decisão, quando já não tinha mais nada a ser feito e a desgraça assolava as ruas de Tebas, oportunidade em que reconhece a arbitrariedade de sua conduta e as consequências que ocasionou àquele povo. 
A tragédia se encerra com uma mensagem aconselhadora do coro ao acompanhar a lenta retirada de Creonte:

Destaca-se a prudência sobremodo como a primeira condição para a felicidade. Não se deve ofender os deuses em nada. A desmedida da empáfia nas palavras reverte em desmedidos golpes contra os soberbos que, já na velhice, aprendem afinal prudência (SÓFOCLES, 1998, p. 251).

Feitas essas considerações, pode-se afirmar que Sófocles fez com que, a partir de sua tragédia, fosse possível eternizar a conduta dos personagens, fazendo-nos questionar a respeito da própria vida em sociedade, bem como a tensão existente entre o obedecer e o transgredir.

A principal característica da heroína trágica revela-se na sua bravura e sobremaneira na forma dissidente de fazer valer aquilo que acreditava e defendia como justiça, independentemente da maneira que lhe foi colocada. Essa forma como Antígona se estabelece na sociedade política (pólis), remete àquilo que foi exposto sobre o direito natural, confirmando seu caráter irresistível e independente das leis reguladoras originadas do Estado.

Dessa forma, foi o direito natural que permitiu a Antígona valer-se de qualquer medida para defender suas convicções diante de Creonte; eis que usou de sua liberdade para preservar sua própria natureza e, consequentemente, fazer aquilo que seu próprio julgamento lhe indicava como mais adequado.

A ação heroína de Antígona reveste-se de aspectos morais, políticos e jurídicos, visto sua atuação ao contestar a arbitrariedade do Estado e lutar por justiça, bem como o imenso sentimento que a fez preservar a honra de seu irmão. 
A questão abordada na tragédia em análise pode ser trazida aos dias atuais para melhor entender a relação entre o indivíduo e o Estado; as consequências de uma vida comprometida com a lei, bem como as razões que levam a obedecê-la e os motivos que levam a infringi-las.

Frisa-se que a desobediência civil ostenta a intenção de apelo à consciência pública, haja vista que, no caso de Antígona, além de transgredir o édito proibitivo de Creonte, a heroína fez questão de evidenciar sua atitude, com intuito de redobrar a aversão à regra visada, para que, desse modo, fosse possibilitada legitimamente sua negação (OST apud COPETTI NETO, 2006, p. 41).

O desenrolar funesto em torno de Creonte não implica inocência de Antígona e a condenação absoluta do soberano, haja vista que, da mesma forma que Creonte excedeu seu limite quando infringiu a lei dos deuses, Antígona ultrapassou os limites do ordenamento jurídico estatal. Dessa maneira, não é possível visualizar uma derrota das leis do Estado pelas leis dos deuses, mas sim um grande conflito existente entre o indivíduo e as leis estatais. $\mathrm{O}$ problema maior, no entanto, reside na forma excessiva e rigorosa de como a lei estatal é imposta a seus subordinados. Neste sentido, sintetiza Jebb (apud A TRILOGIA TEBANA, 1998):

\footnotetext{
Mas a questão não é um simples conflito entre a lei do Estado e os deveres religiosos; é um conflito entre a Lei do Estado imposta com excessivo rigor, e uma afeição natural colocada acima das leis. Creonte está certo na letra e errado no espírito; Antígona está certa no espírito e errada na letra (p. 15).
}

A tragédia de Sófocles nos permite analisar as implicações de uma vida regrada pelo direito e as possíveis causas do conflito entre o indivíduo e Estado; isto porque o ato de Antígona representa reação a uma forma totalitária de governo, levando-nos ao seguinte questionamento: A transgressão da norma jurídica pode ser justificada pelos erros cometidos por quem a cria? 
Da mesma forma que a Antígona de Sófocles, por exemplo, invoca ativamente as leis naturais contra as ordens de um poder arbitrário, sempre houve consciências humanas para afirmar e reivindicar as razões da verdadeira justiça contra a violência, embora esta se revestisse de todas as formas da legalidade (DEL VECCHIO apud A TRILOGIA TEBANA, 1998, p. 16).

É perceptível a preocupação de Sófocles com o governo tirânico; isto porque, para além do direito positivo e do direito natural, a obra em comento traz à baila a proteção do cidadão ante o poder opressivo, uma vez que Creonte se caracteriza pelas ações arbitrárias que desenvolve na pólis, subtraindo dos integrantes da comunidade as relações de domínio que ocorrem no espaço privado.

A grande celeuma em torno da lei dos homens e da lei natural tem movimentado o espaço jurídico e levantado um debate fervoroso entre o direito natural e o direito positivo e, ainda, a relação (ou não) entre a lei e a justiça.

Não é raro, mesmo nas democracias contemporâneas, as normas jurídicas e os valores morais encontrarem-se numa relação tensa e, por vezes, antagônica, revelando que nem sempre os interesses do Estado e os do indivíduo coincidem e reclamando por uma solução que preserve a eficácia exigida do primeiro - quanto à manutenção e promoção da vida em sociedade - e a liberdade inalienável do segundo - sem a qual a cidadania dá lugar à escravidão moral, o diálogo à violência. $\mathrm{O}$ final trágico de Antígona, com a ruína experimentada por Creonte e a morte da protagonista, convida a pensar que entre a consciência do Estado - expressa através das leis - e a consciência individual (sempre moral em alguma medida) - expressão da liberdade humana de realizar escolhas - instala-se uma tensão que, quando enfraquecida ou rompida, ainda mais de forma violenta, desencadeia ou a dissolução do Estado ou a supressão da liberdade e da vida dos indivíduos-cidadãos (ALVES, 2005, p. 366). 
A dissonância entre o direito natural e o direito positivo, assim como ocorreu a Creonte, pode levar o jurista a uma aplicação errônea da lei, de forma que passe a ser vista somente num sentido literal, independentemente de seu conteúdo ser justo ou injusto.

Hodiernamente, a atuação de Antígona persiste na vida dos indivíduos que reivindicam a sua justiça contra a arbitrariedade ou descaso do Estado, e tal atuação leva a um conflito social que afronta a relação direito natural e direito positivo. Dessa forma, se rompida a relação entre Estado e indivíduo, a consequência trágica será a dissolução do Estado Democrático de Direito.

\section{ENTRE A JUSTICIALIZAÇÃO PRIVADA E O ESTADO DE EXCEÇÃO}

\subsection{Da Violência das Ruas à Violência Institucionalizada}

Pega, mata, lincha!! O rapaz corre. É mulato escuro, franzino, aparenta ter, no máximo, uns 20 anos. Acabara de ser visto "em atitude suspeita" no interior de uma loja e, ao ser perseguindo, abandonara os poucos objetos furtados. Os gritos atraem vizinhos e passantes. Pacatos cidadãos transformaram-se em implacáveis justiceiros: socos, pontapés, pauladas, pedradas ... até mulheres e crianças participam. Tiram-lhe a roupa; uma corda é amarrada no pescoço do indigitado e no rabo de um cavalo, que o arrasta a galope. Enfim, estraçalhado, o jovem morto pela "justiça popular" será levado pela polícia, que mais uma vez nada pôde apurar, sequer a identidade da miserável vítima. Os linchadores têm a consciência tranquiila: "Bandido tem mais é que morrer" (Piabetá subúrbio do Rio de Janeiro, maio de 1981). 
$\mathrm{O}$ acontecimento supranarrado representa, em poucas palavras, como acontecem os linchamentos no Brasil. O caso não foi um episódio isolado acontecido em 1981 e que, de tão bárbaro, não voltou mais a ocorrer. Ao contrário, é somente um exemplo dos vários casos de linchamento que ocorreram e continuam a acontecer até os dias atuais.

A socióloga Jacqueline Sinhoretto define o linchamento como "prática coletiva de execução sumária de pessoas consideradas criminosas” (2001, p. 34). Para ela, a característica diferenciadora de linchamento para outros tipos de execução sumária, consiste em seu caráter de ação única, espontânea e sem prévia organização.

O linchamento se desenrola num plano complexo com a origem, supostamente na palavra Lynch; isto porque não há certeza sobre a verdadeira origem desta palavra. Alguns pesquisadores acreditam que o que chamamos hoje de linchamento teve início nos Estados Unidos, mais precisamente na Fazenda do Coronel Lynch, onde o Fazendeiro executava sumariamente os criminosos e os escravos em fuga em suas terras. Outros acreditam que o ato se originou com o capitão Willian Lynch, da Virgínia, que mantinha um comitê para manutenção da ordem durante a Revolução de 1780. O fato é que, independentemente da origem da palavra, a prática de linchamentos atingiu e continua a atingir vários lugares do mundo, em diferentes épocas.

O sociólogo José de Souza Martins afirma que no Brasil o primeiro caso de violência coletiva consistente no linchamento, pode ter ocorrido em 1585 num território indígena, onde um índio, dirigente de um movimento messiânico em Salvador, teria sido linchado pelos seus próprios seguidores, os quais o maltrataram, cortaram-lhe a língua e o estrangularam. De lá para cá, esses movimentos de violência popular têm cada vez mais destaque no cenário brasileiro. 
No início da década de 90, Caetano Veloso compôs uma música da qual se extrai o seguinte verso: "A mais triste nação, na época mais podre, compõe-se de possiveis grupos de linchadores". ${ }^{1}$ Passados mais de 20 anos, o verso tem se concretizado, mostrando a miséria de uma sociedade composta por linchadores denominados por muitos de justiceiros.

A prática reiterada dos linchamentos exige, neste momento, um estudo sobre esta forma de (in)justiça realizada por intermédio de pequenos grupos da sociedade; isto porque o que a coletividade exprime é também a forma como está sendo tratada.

Cada vez mais os casos de linchamentos têm tomado conta dos noticiários do país. No ano de 2012, no Distrito de Brejo da Madre, em Pernambuco, após ter notícias de que uma criança foi brutalmente assassinada por um grupo de pessoas acusado de realizar rituais malignos com a vítima, a população, indignada, saiu pelas ruas numa caçada medieval com o intuito de punir todos os praticantes de rituais afro-brasileiros. ${ }^{2}$

Mediante notícias veiculadas em jornais e na internet, foi relatada uma situação em que um adolescente de 15 anos, no dia 31 de janeiro de 2014, foi acorrentado nu a um poste no Bairro Flamengo, no Rio de Janeiro. $\mathrm{O}$ adolescente tinha uma orelha cortada e marcas de espancamento por todo o corpo, e era acusado de praticar furtos na zona sul carioca. A cidade maravilhosa teve seu brilho escondido diante das atitudes dos justiceiros, os quais tomaram para o si o jus puniendi pertencente ao Estado. ${ }^{3}$

${ }^{1}$ Veloso, Caetano. O cu do mundo. In: Circuladô [CD]. Rio de Janeiro: Poly Gram, 1991.

${ }^{2}$ Disponível em: <http://oglobo.globo.com/brasil/pe-multidao-tenta-linchar-suspeitos-demagia-negra-5456730>. Acesso em: jul. 2015.

${ }^{3}$ Disponível: <http://www1.folha.uol.com.br/cotidiano/2014/02/1407239-adolescente-eagredido-a-pauladas-e-acorrentado-nu-a-poste-na-zona-sul-do-rio.shtml $>$. Acesso em: jul. 2015 . 
No dia 3 de maio de 2014, a senhora Fabiane Maria de Jesus foi violentada no litoral de São Paulo. A dona de casa morreu após ser linchada por um grupo de populares de uma comunidade do Guarujá em razão de ter sido confundida com um retrato falado de outra mulher suspeita de sequestrar crianças para rituais de magia negra. Desta vez, a pena recaiu sobre uma pessoa inocente. ${ }^{4}$

O professor de História, André Luis Ribeiro, faz um relato sobre a onda de violência no ano de 2014. Segundo ele, desde o caso do adolescente amarrado no poste até a morte de Fabiane Maria de Jesus, foram noticiados mais de 50 casos de linchamentos, o que revela a intolerância popular e as cenas bárbaras que fazem vítimas por todo o país.

É assustadora a forma como têm se multiplicado nos noticiários da imprensa brasileira as informações acerca desse fenômeno social e o modo como tem se tornado perigosamente contumaz em nossa sociedade.

Os linchamentos expressam a crise existente entre o povo e o poder, entre a sociedade e o Estado, entre o real e o legal. Como valor de justiça, o linchamento encontra-se em conflito com a justiça estatal e de seus mecanismos próprios de resolução pública de conflitos. Este fenômeno trágico, de modo geral, traduz a insegurança em relação à proteção que a sociedade deve(ria) receber do Estado, quando este não se mostra capaz de cumprir com suas funções constitucionais.

Por meio das pesquisas realizadas pelo sociólogo José de Souza Martins, é possível visualizar que nos últimos 60 anos cerca de um milhão de brasileiros já participou de, pelo menos, um ato de linchamento ou de uma tentativa de linchamento. Este número mostra que o justiçamento

${ }^{4}$ Disponível em: <http://g1.globo.com/sp/santos-regiao/noticia/2014/05/mulher-mortaapos-boato-em-rede-social-e-enterrada-nao-vou-aguentar.html>. Acesso em: jul. 2015. 
popular nos dias de hoje já faz parte da realidade social e vem perdendo sua característica de fato excepcional, colocando em choque a justiça do povo e a justiça dos tribunais.

Esses casos de anomia social sugerem um enraizado sistema de valores subjacente ao comportamento coletivo violento, bem como um difícil acordo entre a lei e a justiça.

Neste sentido, leciona o sociólogo José de Souza Martins:

O linchamento não é uma violência original: é uma segunda violência. Está fundamentalmente baseado num julgamento moral. É, sobretudo, indicativo de que há um limite para o crime, para o delito e, por incrivel que pareça para a própria violência - há o crime legítimo, embora ilegal, e o crime sem legitimidade (2015, p. 54).

Quando são praticados linchamentos se torna evidente o julgamento da justiça legal pela justiça popular, pois, de acordo com Martins (2015a, p. 27), “o linchamento não é uma manifestação da desordem, mas de questionamento da desordem”. Assim, a população lincha para punir, mas sobretudo para manifestar o descontentamento com as alternativas apresentadas pelo Estado.

Como no caso de Antígona, que, apesar de pôr à tona a questão da desobediência civil, aqui se iguala no que diz respeito ao embate existente entre o direito natural (justiça) e o direito positivo (lei). Por mais que o ato de linchar seja considerado contrário à justiça legal, no momento em que ocorre é evidente o clamor pela justiça inerente à pessoa; não que o direito natural evocado pelo linchador sirva de justificativa para o não cumprimento do direito positivo, mas é evidente que, diante de sua insatisfação com o Estado, para o praticante do ato mais vale a ofensa à lei positivada do que o desprezo a seus aspectos morais e sua própria concepção de justiça. 
Neste cenário de crise social pode-se notar o evidente retrocesso do homem ao seu estágio primitivo, que Hobbes denominava estado de natureza. A teoria hobbesiana aborda que o homem no estado de natureza se encontra numa condição contrária à civilização. É nesse momento que ele depende exclusivamente do uso da força para preservar a sua segurança, porquanto não há Estado, uma vez que todos os indivíduos estão num estado de igualdade natural.

Ante a ausência de restrições individuais e a possibilidade de todos desfrutarem de suas paixões individuais sem existir um poder comum a todos, a guerra é inevitável. É o que leciona Hobbes (1979, p. 79): "Durante o tempo em que os homens vivem sem um poder comum capaz de mantê-los a todos em respeito, eles se encontram naquela condição a que se chama guerra; e uma guerra que é de todos os homens contra todos os homens".

Quando a pessoa adota a máxima "olho por olho e dente por dente” e opta por fazer justiça com as próprias mãos, ela se coloca em um momento de estado de natureza, como ser selvagem, alguém que vive sem lei, como se tivesse todos os direitos e nenhum dever. É nesse estado que a vida em sociedade se mostra insegura e ameaçadora e os indivíduos são vistos como inimigos uns dos outros, como bem expõe Hobbes:

Portanto tudo aquilo que é válido para um tempo de guerra, em que todo o homem é inimigo de todo o homem, o mesmo é válido também para o tempo durante o qual os homens vivem sem outra segurança senão a que lhes pode ser oferecida por sua própria força e sua própria invenção (HOBBES, 1979, p. 46).

Nos casos de justiçamento popular, a sociedade ignora a legitimidade do Estado para reprimir o crime, julgar e punir o infrator, sob a justificativa da ineficiência estatal. 
À luz dos ensinamentos de Hobbes, neste ambiente de justiça com as próprias mãos o homem é visto como o lobo do homem, fazendo crer que o indivíduo violento, estúpido e de poucas luzes, presente na época de Hobbes, também se faz presente na pós-modernidade.

Em pleno século XXI, mesmo depois da revolução industrial, da revolução francesa, da revolução tecnológica e da revolução comunicacional, grande parcela dos habitantes da Terra vive a barbárie da "vida solitária, miserável, sórdida, brutal e curta”, que caracteriza o "estado de natureza”. Em plena era da pós-modernidade muitos seres humanos continuam mais preocupados com a sobrevivência que com a própria convivência (BIANCHINI; GOMES, 2015).

A busca pela justiça além dos limites estabelecidos por lei, desfaz a ordem social e faz com que o homem retroceda a seu estágio primitivo por meio de um processo contrário ao Estado Democrático de Direito, como bem memora Thiago Fabres de Carvalho:

[...] o estado de natureza representa um estado de absoluta ausência de normas, de liberdade excessiva tanto quanto de luta excessiva, ao ganhador desta guerra incumbe determinar o que é a norma, e ao perdedor resta submeter-se a essa determinação $(2005$, p. 8$)$.

Denota-se, então, que esta desumana forma de justiça confronta a própria estrutura do Estado Democrático de Direito e se assemelha às abomináveis condenações da Inquisição ao longo do período colonial, uma vez que retiram do indivíduo infrator todos os direitos e garantias trazidas pela Constituição Federal de 1988.

Com efeito, a prática de linchamento revela aspectos significativos no quadro de violência contemporânea, e o que não se pode olvidar é a relação destas condutas à incorporação de métodos mais violentos pelo Estado, representado pela polícia. É claro que é de fundamental importân- 
cia a atuação de uma polícia responsável, ainda mais nesses momentos de desordem social. O cenário atual, no entanto, revela a atuação arbitrária e desenfreada dos agentes estatais incumbidos do combate à violência.

No Brasil, é comum que policiais sejam frequentemente imputados por atos cometidos de forma arbitrária. As polícias Civil e Militar sofrem grandes acusações de prática de tortura nos acusados pelo cometimento de algum delito, o que mostra uma contradição insuperável com a função constitucional da polícia, qual seja: garantir a segurança pública com a preservação da ordem pública e da incolumidade das pessoas e do patrimônio (artigo 144 da CF/88).

Sobre este assunto, José de Souza Martins explica que

Quando a defesa das instituições é feita pelo policial cumpridor da lei e cidadão, que felizmente há em grande número, respeitador dos direitos dos outros, competente no exercício de sua profissão perigosa, podemos dormir em paz. Mas quando a civilidade é deixada ao léu das motivações da rua ou a defesa da lei e do direito é posta nas mãos de policiais que agem em nome próprio ou de grupos corporativos com interesses que escapam das razões de Estado, temos a podridão instalada no seio da sociedade e das instituições. A desordem regulando a ordem, a morte regulando a vida. A chacina destes dias apenas nos diz que estamos presenciando também a chacina das instituições (2015b, p. 132).

Dessa forma, é de se preocupar não somente com o indivíduo que adere à violência como forma de resolução de litígio, mas também com o exemplo que o Estado tem dado à sociedade, uma vez que, ao invés de buscar construir pontes democráticas de compreensão política e punição adequada aos possíveis grupos de linchadores, prefere fomentar a anseio punitivo por meio de uma lógica que acredita que somente com a violência - seja por pessoas ou seja pelo Estado - é possível resolver os conflitos. 
Sobre o assunto, Adauto Suannes levanta uma série de questionamentos:

Qual o remédio que temos hoje para situações como essas [criminalidade, ou a violência tipificada] e tantas outras semelhantes? Aplicar sobre o violento uma violência "aceitável", por isso que provém do Estado. Mas quais os preceitos éticos que informam a aplicação dessa contra-violência por parte dos agentes do Estado? Essa violência oficial inibe outras pessoas de infringir a lei? O punido sairá do presídio convencido (lembremos que um dos nomes que outrora se dava aos condenados era precisamente esse: convicto) de que, de fato, “o crime não compensa”? Será justificável que se gaste tanto dinheiro na repressão do crime, sem nos determos em suas causas? Eis o drama que as sociedades modernas - a nossa em especial - não conseguem equacionar adequadamente (apud SILVA, 2015).

A realidade mostra que o Estado/governo está pouco preocupado com as respostas para essas indagações. $\mathrm{O}$ índice de violência por parte do Estado aporta que alguns setores da sociedade também estão dispostos a matar com as próprias mãos. Tanto os linchamentos quanto os massacres revelam a recriação anômica da sociedade: “[...] o modo como a coisa foi feita constitui o recado certeiro às autoridades e ao povo de que temos governo, mas não tanto, temos polícia, mas não tanto, temos justiça, mas não tanto" (MARTINS, 2015b, p. 129).

\subsection{A Emergência do Homo Sacer no Cenário Brasileiro}

Os casos de justiçamento popular ante o poder estatal remetem ao que Aristóteles pregava sobre a vida enquanto zoé, entendida como meramente natural, ou seja, o indivíduo considerado apenas como um ser vivente. Uma mera existência. Para o filósofo, a zoé diferencia-se da bios (politikón zôon), porquanto esta é caracterizada pela possibilidade de o 
homem ter uma vida política. É neste contexto de biopolítica que o filósofo italiano Giorgio Agamben insere o conceito de homo sacer, em que traz a questão da vida nua (zoé) e da vida politizada (bios).

Segundo o filósofo, a vida nua tem início na figura do homo sacer, cuja característica principal consiste na sua condição de insacrificável, porém matável, isto porque na comunidade romana o homo sacer era aquele indivíduo condenado em razão da prática de algum delito e que, por este motivo, não poderia ser sacrificado aos deuses, mas se alguém o encontrasse poderia matá-lo sem receio algum de ser punido pela prática de homicídio.

[...] Assim como na exceção soberana, a lei se aplica de fato ao caso excepcional desaplicando-se, retirando-se deste, do mesmo modo o homo sacer pertence ao Deus na forma da insacrificabilidade e é incluído na comunidade na forma da matabilidade. A vida insacrificável $e$, todavia, matável, é a vida sacra (AGAMBEN, 2004, p. 90).

Nota-se, então, que o que define a condição do homo sacer não é somente a ambivalência de sua sacralidade (uma vez que se encontra entre o jus divinum e o jus humanum), mas também o caráter particular da violência em que é exposto, bem como da dupla exclusão em que se encontra preso.

Feitas essas considerações, é possível trazer a figura do homo sacer romano para a atualidade brasileira, onde a vida humana é colocada sob um regime de anomia, quando é feito o que Agamben denominou de tanatopolítica: o poder do soberano de decidir qual vida merece ser vivida, ou seja, quem - apesar de insacrificável -, pode ser matável.

O marginal é o pária da sociedade. É aquele indivíduo degenerado, que merece ser punido exemplarmente e se possível excluído definitivamente da sociedade. Marginal é o bandido, aquele ser abjeto, repugnante e cujo ódio que ele mesmo causa justifica a recente onda de linchamentos. É o homo sacer (AGAMBEN apud SANTOS JUNIOR, 2015). 
É a partir desta condição humana que o Estado se privilegia enquanto detentor do poder sobre a vida (biopolítica), e coloca o homo sacer na constante incerteza de vida, uma vez que tal personagem enfrenta a possibilidade de, a qualquer momento, ser impunemente eliminado da sociedade, seja pelo membro da comunidade, seja pelo Estado.

Como bem-leciona Carvalho (2005, p. 12), “a dimensão política do homo sacer, o vínculo (oculto) que o liga ao poder soberano, consiste justamente no fato de que, ao ingressar na vida politicamente qualificada, o indivíduo o faz concedendo ao soberano um direito de vida e morte sobre ele”. Nesta acepção, cabe ao poder soberano decidir sobre a inclusão ou exclusão do homem do grupo social, a relevância política da vida dos indivíduos e a eliminação da "vida sacra" daquele que não precisa mais fazer parte da sociedade.

Evidencia-se, deste modo, a emergência do espectro do homo sacer da comunidade romana no cenário brasileiro de incessantes infortúnios decorrentes do círculo vicioso da violência, onde os direitos humanos são constantemente desmerecidos pelo poder soberano.

De fato, consoante sugere a tese de Agamben, o homo sacer é sem dúvida o arquétipo (ideal-típico) do homem contemporâneo. Cada vez mais privado da referência da autoridade, privado tanto da lei positiva quanto da eficácia dos direitos humanos, o homem vê-se diante da terrível diáspora de sua vida “matável e insacrificável”. Embora proclamada por extensos catálogos de direitos fundamentais dos Estados Constitucionais contemporâneos, a vida digna (sacra) esbarra na dinâmica da exceção e da urgência, tornando-se facilmente descartável, e necessariamente desperdiçada (CARVALHO, 2005, p. 13). 
Como bem se nota, é no contexto político de exceção, que será mais bem abordado no próximo tópico, que é encontrada a figura do homo sacer, porquanto é neste espaço essencialmente vazio que se instala a vida nua, submetida aos desígnios do soberano, o qual, na sua insaciável sede de agir em exceção, decide qual vida merece ser vivida.

\subsection{Violência Legitimada: quando a exceção se torna regra}

O aumento do índice de violência na atualidade brasileira e o constante desencontro entre a carta constitucional e a prática, sugerem uma realidade triste e aterrorizante que se concretiza na forma como o Estado se impõe perante a sociedade, estabelecendo-se por meio de um modelo de exceção usado como paradigma de governo da política contemporânea.

Historicamente, o estado de exceção - iustituium - tem origem romana e representa o ponto de desequilíbrio entre o direito e a política, segundo o qual o Senado poderia solicitar, àquele que detivesse o poder, a adoção de medidas sanatórias quando a continuidade institucional do Estado estivesse ameaçada.

O conceito jurídico de estado de exceção aponta um mecanismo político e antidemocrático utilizado, temporariamente, para suspender o Estado de Direito a fim de restabelecer a ordem institucional. Nesta situação, o Poder Executivo pode, desde que dentro dos limites constitucionais, tomar atitudes que limitem os direitos das pessoas. Assim, o estado de exceção representa uma zona de risco à supremacia dos direitos fundamentais e às funções essenciais do Estado Democrático de Direito.

A atual Constituição Federal trouxe o mecanismo de exceção ao tratar do estado de sítio em seu artigo 137, ipsis litteris:

Art. 137. O Presidente da República pode, ouvidos o Conselho da República e o Conselho de Defesa Nacional, solicitar ao Congresso Nacional autorização para decretar o estado de sítio nos casos de: 
I - Comoção grave de repercussão nacional ou ocorrência de fatos que comprovem a ineficácia de medida tomada durante o estado de defesa; II - Declaração de estado de guerra ou resposta a agressão armada estrangeira.

Parágrafo único: O presidente da República, ao solicitar autorização para decretar o estado de sítio ou sua prorrogação, relatará os motivos determinantes do pedido, devendo o Congresso Nacional decidir por maioria absoluta (BRASIL, 1988).

Com efeito, inobstante a Constituição Federal elencar restritamente as hipóteses de uso dessa medida, o que os tempos atuais revelam é a prática recorrente a este instituto de exceção e a confirmação do pensamento de Carl Schmitt, ao afirmar que "soberano é aquele que governa em estado de exceção - Ausnamezustand”. Para Schmitt (apud BERCOVICI, 2004), somente a exceção permite que se chegue à essência do direito.

Este espaço de anomia - onde tem lei, mas não tem - pode ser visualizado em todos os regimes de característica ditatorial que tem por objetivo legitimar a suspensão dos direitos das pessoas e, assim, instaurar a força imperativa do Estado para, posteriormente, retornar ao Estado Democrático de Direito.

Em sua concepção atual, o estado de exceção é visto a partir do conceito jurídico-constitucional da Constituição alemã de Weimar, a qual abria, como medida excepcional, a possibilidade de suspender os direitos das pessoas para restabelecer a ordem pública abalada pelas grandes calamidades.

A constituição de Weimar foi elaborada sem maiores claras, em um contexto político cujo equilíbrio era precário e instável. Desta forma, não era uma Constituição homogênea, monolítica, mas uma expressão das relações entre as forças políticas em disputa em 1919 (BERCOVICI, 2004, p. 26). 
Em verdade, a Constituição de Weimar buscava estabelecer uma nova ordem econômica alterando aquela existente na época de sua elaboração. Assim, ela serve de baluarte para colaborar com a ideia de que a constante recorrência aos mecanismos de exceção pode alterar de maneira trágica toda a estrutura do Estado e, por fim, as garantias de forma duradora.

Foi na Alemanha, durante a passageira República de Weimar, que a democracia se viu ameaçada pelo estado de exceção e deu espaço para um regime totalitário. Este período foi marcado pela teoria de Carl Schmitt sobre a soberania no estado de exceção.

Se, no Reich alemão, a segurança e a ordem pública estiverem seriamente [erheblich] conturbados ou ameaçados, o presidente do Reich pode tomar as medidas necessárias para o restabelecimento da segurança e da ordem pública, eventualmente com a ajuda das forças armadas. Para esse fim, ele pode suspender total ou parcialmente os direitos fundamentais [Grundrecht], estabelecidos nos artigos 114, 115, 117, 118, 123, 124 e 153 (AGAMBEN, 2004, p. 28).

Nota-se que Agamben faz uma interpretação do artigo 48 da Constituição de Weimar e demonstra a verdadeira hipótese de suspensão dos direitos trazidos pela mesma carta política. $\mathrm{O}$ referido artigo assegurava ao Soberano poderes excepcionais para garantir o exercício de suas funções políticas durante o período de ameaça ou conturbação da ordem pública.

O governo da República Alemã, por meio da declaração do estado de exceção, promulgou mais de 250 decretos de urgências que serviram para prender militantes comunistas e instituir tribunais especializados em decretar condenações à pena de morte (AGAMBEN, 2004).

Agamben sugere que foi este cenário, que submergia a Alemanha, que possibilitou a entrada do Nacional Socialismo ao poder. 
Sabe-se que os últimos anos da República de Weimar transcorreram inteiramente em regime de estado de exceção; menos evidente é a constatação de que, provavelmente, Hitler não teria podido tomar o poder se o país não estivesse há quase três anos em regime de ditadura presidencial e se o Parlamento estivesse funcionando. [...] O estado de exceção em que a Alemanha se encontrou sob a presidência de Hidemburg foi justificado por Schmitt no plano constitucional a partir da ideia de que o presidente agia como "guardião da constituição" (Schmitt, 1931); mas o fim da República de Weimar mostra, ao contrário e de modo claro, que uma "democracia protegida" não é uma democracia e que o paradigma da ditadura constitucional funciona sobretudo como uma fase de transição que leva fatalmente à instauração de um regime totalitário (AGAMBEN, 2004, p. 29).

O professor Gilberto Bercovici (2004) insinua que a análise de Carl Schmitt e a proposta do estado de exceção, representam as relações contemporâneas entre o Estado e a economia; isto porque há um predomínio da classe que controla o capital sobre as demais, o que demonstra um enfraquecimento da estatalidade. Alude, ainda, que "a ditadura política foi substituída pela ditadura econômica dos mercados” e que, em razão da desestruturação do Estado, esse modelo de emergência tem cada vez mais tomado espaço nos países democráticos contemporâneos, e tende, infelizmente, a tornar a exceção regra.

Como bem memora Bercovici (2004, p. 171), "A periferia vive em um estado de exceção econômico permanente, contrapondo-se à normalidade do centro". Denota-se que o decisionismo que Carl Schmitt fazia menção é sobremaneira evidente nas grandes regiões periféricas, onde as decisões de emergência são contínuas e os direitos fundamentais constantemente suspensos, a fim de manter a ordem social e, principalmente, a ordem econômica.

É também na periferia que a figura do homo sacer - principal vítima do soberano que governa em exceção - se torna patente. É na periferia que a vida é insacrificável (o Estado não pode explicitamente matá-la), 
porém matável (o estado pode implicitamente deixar matá-la). É na periferia que os direitos da pessoa perdem lugar pelo corpo do homem sacro e pela vida nua.

Enquanto objeto do poder soberano, os valores da igualdade e da dignidade humana parecem refugar diante do altar da cultura do individualismo possessivo, em virtude do acionamento global de estratégias perversas de poder, impulsionadas pela lógica da expansão dos mercados e por padrões de superioridade racistas, étnicos, culturais e ideológicos (CARVALHO, 2005, p. 13-14).

O vazio de direito que envolve os circuitos expõe um estado violador de direitos e garantias fundamentais, marcado pela fomentação da desigualdade social, pela seletividade arbitrária e pela exceção permanente, o que reflete de maneira considerável no quadro da violência atual.

De acordo com Agamben (2004), o estado de exceção encontra relação com a guerra civil em razão da insurreição e da resistência que ocupam lugares nesse espaço vazio, pois a guerra civil se situa numa região de indecidibilidade como no estado de exceção, que vai de encontro ao estado normal e corresponde à resposta imediata do poder estatal para resolver os conflitos mais extremos.

As características deste modelo se revelam na forma como o cidadão (visto como homem nu) fica à mercê dos desígnios do poder Soberano, poder este que o coloca numa condição de invisibilidade e, assim, reproduzem fenômenos políticos de exclusão. É o soberano que possui o poder de inclusão e exclusão do homem na sociedade e, justamente nisto, consiste o estado de exceção.

Agamben (2004) também afirma que a criação voluntária de um estado de emergência permanente já se tornou habitualidade nos estados contemporâneos, inclusive nos chamados democráticos. Este paradigma atual de biopolítica, quando o soberano somente consegue governar sob a forma de exceção, mostra o verdadeiro retrocesso de todas as conquistas 
trazidas no âmbito do direito, mormente o próprio Estado Democrático de Direito. Afora essa circunstância, desvaloriza determinado grupo de indivíduos e ignora sua vida política.

O semblante dessa nova ordem tende a expressar a compleição excludente e desumana de sua biopolítica. Sobretudo em face da prevalência do mercado nas relações sociais, os indivíduos encontram-se radicalmente expostos às suas forças descontroladas, como se a decomposição das proteções institucionais traduzisse a regressão ao estado de natureza econômico e social (CARVALHO, 2005, p. 15).

É diante deste panorama de crise econômica e social que o Estado se impõe de maneira repressiva e arbitrária sob a justificativa de preservar a ordem nacional e, com isso, excita cada vez mais os anseios violentos dos membros da sociedade. "E, como se sabe, são os fracassos da política e da democracia como alternativa à violência que determinam o uso da força e da repressão como mecanismo de gestão de conflitos” (CARVALHO, 2005, p. 15).

O oposto do Estado Democrático de Direito é o estado de exceção. Essa expansão totalitária provoca um desconforto na população que achava estar protegida pelo aparato de normas, conquistado com o advento da Constituição da República Federativa do Brasil. Ademais, é o estado de exceção, como ato político, que concede ao Soberano amplos poderes para decidir sobre a biopolítica e, inclusive, instalar a espécie de “ditadura constitucional” formulada por Carl Schmitt.

la vida en las actuales ciudades de los Estados nacionales y constitucionales occidentales es esencialmente idéntica a la vida en un campo de concentración nazi. Las decisiones del Estado, de sus funcionarios, sobre el estatuto jurídico de, por ejemplo, un embrión humano, o de un colectivo de inmigrantes sin papeles, o de un grupo de presos preventivos 0 , incluso, sobre cualquier ciudadano, son esencialmente idénticas a las decisiones del Estado nazi sobre el estatuto (jurídico, político, antropológico) de un judío. Los sistemas jurídicos occidentales descan- 
san en una ficción que permite la mayor exclusión conocida de la vida. Todos los ciudadanos somos, pues, habitantes de un gigantesco campo de concentración, cuya terrorífica actualidad se oculta tras la máscara de la democracia (HERVÁS apud CARVALHO, 2005, p. 15).

Com efeito, a questão da violência, seja ela privada ou institucional, vai muito além de um fato social e se aloja no contexto político do Estado, posto que a vinculação subjacente entre violência e direito é instalada na ausência de lei, ou melhor, na suspensão dela. Este fator é verificado nos Estados contemporâneos que frequentemente exercem a violência por meio da ilusão de estar governando sobre um espaço vazio de direito (estado de exceção). Como bem-ressalta Santos (2005, p. 260) "a violência governamental que deriva dessa pretensa manifestação jurídica ameaça tornar essas duas esferas - a violência e o direito - "indiscerníveis"”.

Longe de agir de forma violenta, é necessário que o Estado desempenhe uma função social que nem sempre coincida com os fins subjetivos dos homens que o formam, devendo se justificar na representação e organização necessárias para assegurar o direito em uma determinada etapa de sua evolução histórica (BERCOVICI, 2004).

Neste mesmo sentido:

[...] o Estado não necessita fazer um "Estado de exceção" para alcançar seu desiderato. Ele não precisa se igualar. Precisa tomar medidas profiláticas e, depois, preventivas. Voltar a ser "Estado". Estatuir. Definir onde está o limite entre civilização e barbárie. Assim começou a modernidade! Necessita apenas usar os mecanismos institucionais que estão à disposição. Sem abrir mão das garantias - como em qualquer democracia avançada - enfrentar o "bando soberano" que atormenta a sociedade. Antes que esse "bando" crie filhotes, em outros Estados (STRECK, 2012).

A permanência do estado de exceção revela-se como absolutamente perigosa, porquanto anula o estado jurídico do indivíduo em favor da autoridade soberana e o coloca na linha tênue que se forma entre democracia 
e totalitarismo. A manutenção dessas medidas excepcionais usadas pelo Estado como paradigma de governo é incompatível com o atual Estado Democrático de Direito e, sem seu exercício sistemático, pode levar à extirpação da democracia.

Sobre a consequência dessa incomplacente forma de governo, importante são as palavras de Gilberto Bercovici:

O estado de exceção está se espalhando por toda a parte, tendendo a coincidir com o ordenamento normal, no qual, novamente, torna tudo possível. Desta forma, o estado de exceção está se tornando uma estrutura jurídico-política permanente e o paradigma dominante de governo na política contemporânea, com a ameaça de dissolução do Estado. Para Agamben, é o anúncio do novo nomos da Terra, que tenderá a se espalhar por todo o planeta (2004, p. 180).

Neste viés, o mecanismo de exceção não se mostra como a ferramenta adequada para o restabelecimento da ordem social. Longe disso, se apresenta como forma de dominação consubstanciada na manutenção de poder da classe dominadora. Esta medida, legalmente trazida pelo nosso ordenamento jurídico, não pode servir como justificativa para o arbítrio do Estado. Afinal, o direito é o limite da atuação do poder e não o fomento para o seu crescimento.

\section{CONSIDERAÇÕES FINAIS}

A prática reiterada da justiça privada como meio imediato de resolução de conflitos sociais, revela uma conturbada relação entre o direito e o indivíduo no Estado e expõe um verdadeiro conflito entre a concepção de justiça do indivíduo e a aplicação da justiça estatal, e é neste cenário que se traz à baila a questão da legitimidade das normas e o grande desafio de viver sob o amparo do direito. 
Neste enfoque, verifica-se a tensão existente entre o direito positivo, visualizado por intermédio da lei, e o direito natural na sua concepção de justiça, e é a partir do ato de Antígona que se pode melhor compreender esta questão, uma vez que a obra de Sófocles revela um dos maiores e importantes embates entre o direito natural e o direito positivo.

Antígona desobedeceu ao édito proibitivo de Creonte em nome das leis eternas trazidas pelos deuses e, portanto, mais justas em sua própria consciência.Esta desobediência ao Estado, detentor de todo poderio de Tebas, no entanto, tem como consequência trágica a morte da heroína, revelando um insuperável desencontro entre o direito natural e o direito positivo.

A obra imortal de Sófocles propõe um ensaio comparatista e contemporâneo acerca da dificuldade encontrada entre o indivíduo e sua submissão ao poder estatal, a qual pode ser verificada nos casos de justicialização privada, em que um determinado grupo da sociedade deslegitima o poder de punir do Estado a fim de impor suas penas àquele que praticou algum delito.

Esta assombrosa forma de se fazer justiça demonstra um alto grau de insatisfação popular em relação à atuação estatal no combate à violência. Assim, é de se preocupar não somente com o indivíduo que adere à justiça popular, mas também como a forma que o estado se impõe na sociedade, isto porque a banalização da violência tem se tornado marco da sociedade contemporânea, traduzindo uma ameaça à paz social e criando, também, um estado de exceção - anomia - com a expectativa de manutenção da ordem jurídica.

No atual panorama de violência em que submerge a sociedade brasileira, é possível constatar que o apelo ao estado de exceção acontece tanto no público quanto no privado - seja por parte do Estado, seja por parte da população no geral - que somente respondem aos problemas sociais de maneira egoísta e violenta. 
Nesta linha, a conduta do justiceiro se mostra como reflexo do Estado no qual está inserido e de toda a violência que acompanha a sua história; eis que existe um conjunto de concepções sobre segurança que está intimamente ligado à cultura da punição, caracterizada pelo emprego da dor, encarceramentos em massa e punições que violam os direitos humanos.

Diante da constante violação aos direitos fundamentais do cidadão, é normal que a sua vida na sociedade seja vista como uma vida nua e sem qualquer valor político para o Soberano que, segundo Carl Schmitt, governa em estado de exceção.

Desta feita, o sujeito que é justiçado pelos populares ou até mesmo pelo Estado, tem uma vida sacra e que muito se assemelha à figura do homo sacer da comunidade romana: um indivíduo insacrificável, porém matável! Este indivíduo não tem direitos resguardados apesar da lei que vige, o que revela a preocupante possibilidade de um estado de exceção permanente como bem-expõe o professor Gilberto Bercovicci, isto porque o panorama atual sugere que ao Soberano é dado o poder de decidir a quem a lei deve ser aplicada, quais direitos merecem ser resguardados e, consequentemente, qual vida merece ser vivida!

O Estado não cumpridor da lei é um estado totalitário em que muito se iguala ao regime nazista (que também se deu em forma de exceção). Assim, se o Estado dito como Democrático de Direito, por simples conveniência do soberano, não cumpre seu dever constitucional de promover a paz social e efetivar os direitos e garantias fundamentais, não seria este um Estado anômico e incompatível com a Constituição da República Federativa do Brasil?

Os problemas relacionados ao indivíduo e à lei, a justicialização privada e o consequente estado de exceção, apontam a verdadeira crise do Estado Democrático de Direito, o qual necessita urgentemente ser a base para a resolução dos conflitos. 
No pensamento de Carl Shimitt, o estado de exceção não é um problema jurídico propriamente dito, contudo o que as circunstâncias revelam é que, além de um problema jurídico (posto que constantemente são desrespeitadas as leis postas em vigência), o problema central desta pesquisa gira em torno de uma crise social e política.

A partir do estudo apresentado nascem algumas indagações acerca do papel que o Estado tem feito para mudar este cenário. O que cada indivíduo tem desempenhado perante a sociedade atual? Como cada pessoa tem desafiado o Soberano?

Seguindo as palavras de Eduardo Galeano, "somos o que fazemos, mas somos, principalmente, o que fazemos para mudar o que somos" . ${ }^{5} \mathrm{E}$ necessário que cada indivíduo (re)aja ao estado de exceção que se arrasta na vida privada, bem como às atitudes excepcionais do Estado. Não cabe somente assistir a esse espetáculo do horror, comprovando o que dizia Heráclito: "Despertados, eles dormem!"

A solução para o problema atual da violência consiste na maneira com que cada pessoa busca construir algo melhor de forma a transcender a mera existência e deixar de ser a re(criação) anômica do que reflete $o$ estado.

\section{REFERÊNCIAS}

A TRILOGIA TEBANA/Sófocles. Tradução do grego, introdução e notas Mário da Gama Kury. 8. ed. Rio de Janeiro: Ed. Jorge Zahar, 1998. AGAMBEN, Giorgio. Estado de exceção. São Paulo: Boitempo, 2004. . Homo sacer - o poder soberano e a vida nua. $2^{\mathrm{a}}$ reimpressão. Belo Horizonte. UFMG, 2007.

${ }^{5}$ GALEANO, Eduardo (1940-2015). 
ALVES, Marcelo. Uma leitura crítica de Antígona para o Direito. Novos Estudos Jurídicos, v. 10, n. 2, jul./dez. 2005.

BENEVIDES, Maria. A violência brasieira. São Paulo: Brasiliense, 1982.

BERCOVICI, Gilberto. Constituição e estado de exceção permanente. Rio de Janeiro: Azougue Editorial, 2004.

BIANCHINI, Alice; GOMES, Luiz Flavio. Carandiru, policía operativa (justiceira) e a "guerra de todos contra todos". JusBrasil. Disponível em: < https:// professoraalice.jusbrasil.com.br/artigos/121814374/carandiru-policia-operativa-justiceira-e-a-guerra-de-todos-contra-todos>. Acesso em: 20 mar. 2015.

BOBBIO, Noberto. O positivismo jurídico: lições de filosofia do direito. São Paulo: Ícone, 1995.

BRASIL. Constituição (1988). Constituição da República Federativa do Brasil. Brasília, DF: Senado, 1988.

CARVALHO, Thiago Fabres de. O direito penal do inimigo e o direito penal do homo sacer da baixada. Revista de Estudos Criminais, Sapucaia do Sul, 2005. COPETTI NETO, Alfredo. Aportes filosóficos à compreensão do princípio da dignidade humana: os (des)caminhos do Direito Constitucional. 2006. Disponível em: <http://livros01.livrosgratis.com.br/cp029549.pdf>. Acesso em: $1^{o}$ jun. 2015.

GOMES, Luis Flávio. Vandalismos e violência policial: barbárie infinita. JusBrasil. Disponível em: <http://professorlfg.jusbrasil.com.br/artigos/121932176/ vandalismos-e-violencia-policial-barbarie-infinita>. Acesso em: 20 mar. 2015.

HOBBES, Thomas. Leviatã ou matéria, forma e poder de um estado eclesiástico e civil. Trad. João Paulo Monteiro e Maria Beatriz Nizza da Silva. 2. ed. São Paulo: Abril Cultural, 1979. (Os pensadores).

MARTINS, José de Souza. As condições do estudo sociológico dos linchamentos no Brasil. Estudos Avançados, vol. 9. Disponível em: <http://www.scielo. br/scielo.php?script=sci_arttext\&pid=S0103-40141995000300022 > . Acesso em: $1^{\circ}$ jul. 2015a.

. Linchamentos: a justiça popular no Brasil. São Paulo: Contexto, 2015b. 
. Linchamentos: o lado sombrio da mente conservadora. Tempo Social; Revista de Sociologia da USP, São Paulo: USP, out. 1996.

NADER, Paulo. Introdução ao estudo do Direito. Rio de Janeiro: Forense, 2014. ROUSSEAU, Jean-Jacques. Do contrato social. Tradução Rolando Roque da Silva. [s.1.]: Ed. Ridendo Castigat Mores, 2002. Disponível em: <http://www. ebooksbrasil.org/adobeebook/contratosocial.pdf>.

SANTOS JUNIOR, Rosivaldo Toscano dos. O que é violência? O essencial é invicível aos olhos. Empório do Direito. Disponível em: <http://emporiododireito.com.br/o-que-e-a-violencia-o-essencial-e-invisivel-aos-olhos-por-rosivaldo-toscano-dos-santos-junior/\#_ftn1>. Acesso em: 10 jul. 2015.

SANTOS, R. D. A violência legitimada: o estado de exceção como regra. Novos Estudos Jurídicos, v. 10, n. 1, jan./jun. 2005.

SILVA, Denival Francisco da Silva. O círculo vicioso da violência: da exclusão social à ação policial; da ação policial à exposição midiática; da exposição midiática ao sistema de justiça, daí ao cárcere; de volta à exclusão social Parte 2. Empório do Direito. Disponível em: <http://emporiododireito.com. br/o-circulo-vicioso-da-violencia-da-exclusao-social-a-acao-policial-da-acao-policial-a-exposicao-midiatica-da-exposicao-midiatica-ao-sistema-de-justica-dai-ao-carcere-de-volta-a-exclusao-social-3/>. Acesso em: 10 jul. 2015.

SINHORETTO, Jacqueline. Os justiçadores e sua justiça: linchamentos, costume e conflito. 2001. Disponível em: <http://www.nevusp.org/downloads/ down175.pdf $>$. Acesso em: 25 jun. 2015.

SÓFOCLES. A trilogia Tebana. Tradução e notas Mario da Gumma Kury. 8. ed. Rio de Janeiro: Jorge Zahar, 1998.

STRECK, Lenio Luiz. As razões pelas quais o Estado não pode se "acadelar". Revista Consultor Jurídico. 2012. Disponível em: <http://www.conjur.com. br/2012-nov-13/lenio-streck-razoes-pelas-quais-estado-nao-acadelar $>$. Acesso em: 20 mar. 2015. 